Alvaro Cadavid*

Profesor de la Facultad de Teología

Universidad Pontificia Bolivariana

Medellin, Colombia

\title{
La investigación sobre la vida de Jesús
}

\section{INTRODUCCIÓN}

Para la reflexión cristológica contemporánea es un asunto de vital importancia la posibilidad de recuperar la humanidad concreta e histórica de Jesús de Nazaret. Es esta una tarea que pretende alcanzar no solo algunos datos de tipo cronológico o geográfico que permitan elaborar un perfil biográfico de Jesús. Se trata más bien de una búsqueda compleja, con una connotación histórico-hermenéutica, que pretende encontrar el perfil de la personalidad humana de Jesús, el misterio y la significación de su persona histórica que está en la base de los relatos evangélicos y de la tradición de la cual ellos quieren ser testigos.

Esta tarea investigativa es siempre necesaria a la fe y a la teología, entre otras, por varias razones (1):

- La búsqueda del Jesús histórico es un aporte para la teología en la medida en que esta debe presentar a la cultura contemporánea el mensaje cristiano con credibilidad histórica. Lo que en última instancia está en juego en esta búsqueda de Jesús es la credibilidad misma de la fe cristiana: asegurar que los evangelios son fieles a la tradición y que esta es fiel en transmitir, iluminada por la claridad de Pascua, la verdad histórica del misterio revela-

(*) Doctor en Teología por la Pontificia Facultad de Teología de Granada-España. Se desempeñó como director académico del Instituto de Teología y Pastoral -ITEPAL- del CELAM (19901993) y director de la revista "Medellín" del mismo Instituto. Entre sus publicaciones se encuentran: Hacer Creíble el Anuncio Cristiano en América Latina, CELAM, Santafé de Bogotá 1988; Los Signos de los Tiempos. Una perspectiva latinoamericana, CELAM, Santafé de Bogotá 1998. Teología fundamental: la credibilidad y sus signos, UPB, Medellín 2000. Actualmente se desempeña como profesor en la Facultad de Teología y coordinador de los postgrados de Teología de la Universidad Pontificia Bolivariana de Medellín-Colombia.

(1) Sobre la importancia de la recuperación del Jesús histórico, ver J. P. MEIER, Un judío marginal. Nueva visión del Jesús histórico. Tomo I: Las raíces del problema y de la persona, Verbo Divino, Estella 2000, 47-57. Acerca del impacto de la investigación sobre Jesús para la cristología ver el interesante artículo de Roger HAIGHT, The Impact of Jesús Reserch, en Louvain Studies 21 (1996) 216-228. (Un resumen de este artículo se encuentra en Selecciones de Teología 146 (1998) 127-134 bajo el título: "El impacto de la investigación del Jesús histórico sobre la Cristología"). 
do por la persona de Jesús y el impacto que él provocó entre sus contemporáneos. De esta manera la confesión central de la fe cristiana y los relatos fundantes de la misma, podrán acreditarse, no como un invento surgido de la fantasía y el entusiasmo desbordante de unos pescadores alucinados por la resurrección de Jesús, sino como la comprensión plena y la recreación de un sentido ya mostrado por Jesús mismo y vislumbrado por sus discípulos desde antes de Pascua.

- La investigación sobre el Jesús histórico es importante para la teología en cuanto dicha investigación llena la fe de contenidos concretos.

- La búsqueda del Jesús histórico no deja convertir la fe en Cristo en una mera doctrina, en un símbolo mítico o en cualquier forma de docetismo o gnosticismo, sino que ante todo recuerda que la fe es fundamentalmente adhesión existencial a una persona que existió en una época y en un lugar determinado.

- La investigación sobre el Jesús histórico no deja caer a la fe ni a la teología en el reduccionismo que implica, como tantas veces se ha hecho, el hacer énfasis solo en la divinidad de Jesús, sino que recuerda que el Jesús resucitado, Hijo de Dios, es el mismo que vivió y murió como judío en la Palestina del siglo I.

- La búsqueda del Jesús histórico rescata los rasgos de su personalidad que presentan una originalidad única en su momento histórico y que constituyen el paradigma de su seguimiento.

- La recuperación del Jesús histórico obstaculiza cualquier intento de reduccionismo ideologizante de su persona, en el sentido de algún ideal individualista burgués o de algún prototipo de acción revolucionaria política. Si se quiere ser fiel y coherente con los datos que la investigación va aportando, la figura de Jesús que va emergiendo choca con cualquier molde preestablecido que se pretenda imponer de antemano. Jesús se presenta en su momento histórico con una originalidad única que remite siempre al insondable misterio de su persona: su íntima e inmediata relación con Dios, su "abbâ" querido; su libertad suprema para realizar su pasión por el reinado de Dios; y su radical y decidida opción por los marginados y considerados "nada" de su sociedad.

Los interrogantes que subyacen a la pregunta por la verdad histórica contenida en los evangelios, y que han guiado la investigación en torno a esta cuestión, se pueden sintetizar en los siguientes términos: ¿Es posible encontrar a Jesús, el que recorrió la Galilea predicando? ¿Qué fuentes de acceso se tienen para llegar a Jesús y qué validez hay que otorgarles? ¿Son fieles las fuentes al acontecimiento que las originó y en qué medida? ¿Existen algunos criterios que permitan hacer alguna valoración de la autenticidad histórica de las fuentes de acceso a Jesús?

Con la finalidad de exponer, a grandes rasgos, la historia de esta investigación se presentarán las más importantes respuestas que en el transcurso de los últimos dos siglos se han dado a estos interrogantes; luego se fijará la atención en los términos como hoy se plantea el problema y la manera como se trata de dar respuesta al mismo. 


\section{LA EVOLUCIÓN DE LOS PLANTEAMIENTOS Y EL ESTADO ACTUAL DE LA CUESTIÓN}

En el proceso de esta investigación se han venido usando algunos términos técnicos cuya significación es conveniente precisar. Se habla del Cristo de la fe, del Jesús histórico y del Jesús real.

Por el "Cristo de la fe" se entiende la proclamación que desde el comienzo del cristianismo se hace de Jesús como Mesías, Señor y Salvador, tal y como la Iglesia lo ha creído, celebrado y anunciado a través de los siglos. Por el "Jesús real" -algunos emplean también el término Jesús terreno, aunque parece no conveniente identificar al Jesús real con el Jesús terreno- se entiende el retrato "razonablemente completo" de la realidad total (relación completa de las palabras y hechos públicos) de la persona de Jesús, tal y como se presentó en la Palestina del siglo I. Este "Jesús real" está irremediablemente perdido en la historia y no está a nuestro alcance ni lo estará nunca al igual que muchos otros personajes del mundo antiguo. Por el "Jesús histórico" se entiende la reconstrucción hipotética y fragmentaria que se hace de él utilizando los recursos y la metodología de la investigación histórica moderna.

Esta investigación es, por lo tanto, una reconstrucción moderna y necesariamente limitada como lo es todo conocimiento histórico. Se puede decir que la historia de la investigación sobre la vida de Jesús es un reflejo de la evolución que ha experimentado la historiografía en los dos últimos siglos, lo cual explica que nuestro conocimiento de Jesús haya ido progresando en la medida que los estudiosos han podido disponer de nuevos datos y de nuevas herramientas metodológicas. De todas maneras, el Jesús encontrado como resultado de la investigación no coincide -y nunca llegará a hacerlo- con la realidad total de Jesús de Nazaret, pero contribuye a conocerlo mejor y, por esta razón, entre más se investigue y se conozca al Jesús histórico tanto más se irá conociendo al Jesús real (2).

\section{LA “ANTIGUA INVESTIGACIÓN"-LA “OLD QUEST”- SOBRE JESÚS (FINALES DEL S. XVIII-1953)}

Hasta mediados del siglo XVIII la cuestión sobre la autenticidad histórica de los evangelios no ponía problemas a nadie. Tanto católicos como protestantes coincidían con las interpretaciones escolásticas, según las cuales los cuatro evangelios se consideraban relatos históricos inspirados por Dios que conservaban fiel y casi literalmente las palabras y hechos históricos de Jesús tal y como fueron transmitidos por sus discípulos después de la resurrección. Las diferencias entre los cuatro evangelios, se decía, se deben a que fueron escritos desde diversos puntos de vista, pero sustancialmente contienen lo mismo.

El problema comienza a finales del siglo XVIII cuando el protestantismo alemán se ve obligado a dar razón de su fe ante las presiones del racionalismo liberal

(2) Sobre estas distinciones, ver la obra ya citada de J. P. Meier, 214-215. 
iluminista. Para responder al racionalismo ilustrado, los teólogos protestantes quieren colocarse en el mismo campo de aquel movimiento y se preocupan por aplicar el método de la crítica histórica a los textos bíblicos de la misma manera que se usaba para cualquier documento literario.

El primero en encarnar esta tendencia racionalista del liberalismo fue Hermann Samuel Reimarus (1694-1768), profesor de lenguas orientales en Hamburgo. El racionalismo en este caso significaba que todo lo que en los evangelios se saliera de una comprensión racional debía ser desechado. A la muerte de Reimarus, uno de sus discípulos, el filósofo deísta Gotthold Ephraim Lessing (1729-1781), publicó en 1774 siete fragmentos de un manuscrito dejado por su maestro (3). El séptimo de estos fragmentos se titulaba: "Acerca del objetivo de Jesús y sus discípulos". En este fragmento, Reimarus, hacía una distinción entre el proyecto de Jesús y la intención de sus discípulos. Según él, el centro de la predicación de Jesús fue la inminencia del reino de los cielos y el llamado a la conversión que él implica. Jesús fue un Mesías político que mediante su reinado quería liberar a los judíos del yugo romano, pero fracasó. Los discípulos decepcionados hicieron un fraude inventando la resurección y presentando a Jesús como un Mesías apocalíptico que habría de volver. De esta manera, para Reimarus, la diferencia entre lo que Jesús proclamaba y el anuncio de los discípulos no es más que el resultado del fraude realizado por sus discípulos. Por lo tanto, no podemos fiarnos de lo que los apóstoles nos dicen sobre Jesús, ya que el testimonio de ellos acerca de él no responde a lo que dijo y enseñó en su vida.

La posición de Reimarus es el comienzo de un período de comprensión de la vida de Jesús marcado por el racionalismo, en el que es posible distinguir tres momentos. Hacen parte de un "primer" racionalismo las vidas de Jesús escritas por J. J. Hess (1774), F. V. Reinhard (1781); J. H. Herder (1797), K. F. Bahrdt (1786) y K. H. Venturini (1806). Los tres primeros hacen una interpretación romántica de la vida de Jesús en la que todavía perviven algunos elementos sobrenaturales. Para Bahrdt Jesús no fue más que un instrumento en las manos de los esenios, cuyo propósito era minar el poder de los sacerdotes y de los fariseos, pero terminó mal. Sus milagros, su muerte y su resurrección no son más que inventos de esa secta secreta. Venturini no ve en Jesús más que un curandero que llevaba siempre consigo su maleta de "médico" para hacer sanaciones, haciendo creer que eran acciones milagrosas. Luego viene un período que se ha llamado con el nombre de racionalismo "clásico" y cuyo principal exponente es Heinrisch Eberhard Gottlob Paulus (4)

(3) Cf. C. H. TAlbert (ED.), Reimarus: Fragment, Fortress, Philadelphia 1971.

(4) Cf. H. E. B. PAulus, Das Leben Jesu als Grundlage einer reinen Geschichte des Urchistentums, 1828. Para Paulus las curaciones son el resultado de medicinas secretas o el fruto de la oración que posee un valor curativo. Los milagros sobre la naturaleza, como por ejemplo el caminar sobre el agua no es más que una ilusión óptica de sus discípulos; la tempestad calmada ocurre porque Jesús manda parar la barca detrás de un montículo donde ya no da el viento, dando la sensación de que el viento ha desaparecido; la transfiguración no es más que el resultado de un efecto de contraluz; la multiplicación de los panes no es más que una invitación a hacer lo mismo que él hizo al compartir con sus doce discípulos los cinco panes que él tenía; la resurrección de Lázaro no era verdad, puesto que este no había muerto verdaderamente. Niega la resurrección de Jesús al decir que su muerte era solo aparente, pues la lanzada le salvó la vida al producirle un estado de catalepsia del que luego sale. 
(1789-1851) quien en 1828 escribe una vida de Jesús, en la que es presentado como un altísimo maestro de moral. Pretende Paulus explicar todo lo sobrenatural en la vida de Jesús de una manera completamente racionalista. Para él el único milagro que hay en la vida de Jesús es él mismo, su nacimiento. El resto de milagros, aunque tienen un núcleo histórico, se pueden explicar según la razón, pues fueron los mismos espectadores quienes tuvieron que recurrir a explicaciones sobrenaturales al no conocer los mecanismos de las leyes naturales que daban razón de los hechos extraordinarios. El último período de este racionalismo es el "tardío" en donde sobresale F. D. E. Schleiermacher (1768-1834), quien también escribió una vida de Jesús publicada póstumamente en 1864 por un discípulo suyo a partir de sus notas de clase. Hace este autor una separación radical entre el Jesús de la historia en los sinópticos y el Cristo de la fe en el evangelio de Juan. Piensa que los milagros que no se puedan explicar racionalmente deben ser negados. Para el caso de la resurrección de Jesús no sabe este autor decidirse entre resurrección o reanimación.

Esta etapa culmina con la publicación de la primera vida extensa de Jesús. La escribió un filósofo y teólogo, discípulo de F. Ch. Baur y de Hegel, llamado David Friedrich Strauss (5) (1808-1874), que moviéndose en una dirección distinta a la de la escuela liberal, lleva adelante el proyecto iniciado por Reimarus y se configura como predecesor de R. Bultmann. Para Strauss es evidente que los evangelios son relatos míticos -aplica a los evangelios la categoría "mito" que ya se había utilizado en el estudio del Antiguo Testamento-, pues poseen elementos que contradicen las leyes de la naturaleza. Estos elementos no históricos no son fruto del engaño, como pensaba Reimarus, sino de la imaginación mítica, que crea narraciones espontáneamente para transmitir una idea. Para este autor, mito no significa algo fantástico o una historia falsa, sino que el mito es más bien un método precientífico y prefilosófico para expresar ideas científicas y filosóficas en forma de narración. El revestimiento mítico no afecta al núcleo de la fe cristiana, que según Strauss era la idea de la humanidad de Dios, realizada históricamente en Jesús. Los evangelios si bien tienen un trasfondo histórico son obras dirigidas fundamentalmente a la fe y no poseen ninguna fiabilidad histórica.

Por esta razón, afirma Strauss, no es posible encontrar a Jesús de Nazaret ni reconstruir su vida, ya que todo lo que aparece en los evangelios es proyección del mito creado por sus discípulos. Niega así Strauss la posibilidad de escribir una vida de Jesús, dados los elementos sobrenaturales y contradicciones que hay en los evangelios. Del evangelio de Juan hay que prescindir totalmente como fuente de información histórica por ser una obra eminentemente teológica y porque en ella se ha llevado más hasta el extremo la tendencia mitificante (6). Según Strauss, las "vidas de Jesús", escritas con anterioridad, habían sido o explicaciones piadosas y ortodoxas, que aceptaban la intervención de lo sobrenatural en la historia humana, o

(5) La obra se publicó en dos volúmenes entre 1835-1836 (Cf. D. F. STRAusS, Das Leben Jesu, kritisch bearbeitet, Tübingen 1935-1936).

(6) Strauss interpretó mal la relación literaria de los evangelios sinópticos entre sí: pensaba que Mateo y Lucas eran los evangelios más antiguos y Marcos una mera síntesis de ambos. Será la posterior teoría de las dos fuentes la que precisará esta relación. 
meras aclaraciones racionalistas de hechos aparentemente sobrenaturales. En su obra Vida de Jesús contrapone ambas explicaciones y señala su insuficiencia para luego demostrar que la interpretación mítica resuelve todos los problemas (7).

En los años siguientes la investigación sobre la vida de Jesús deriva hacia la cuestión sinóptica, cuyo objetivo era "determinar las relaciones existentes entre los evangelios sinópticos y el orden cronológico en que fueron escritos". La investigación pasa entonces del ámbito primordialmente teológico, en el que se discutía el carácter milagroso y trascendente de la vida de Jesús, al campo de la crítica literaria o investigación de los evangelios, considerados como las fuentes auténticas en que se conserva el recuerdo de la historia y de las palabras de Jesús.

De acuerdo con la tradición eclesial se consideraba hasta ese momento que Mateo era el evangelio más antiguo. Lo que era convicción hasta entonces fue puesto en duda por la hipótesis de las dos fuentes, propuesta de modo independiente y simultáneo por Christian Hermann Weisse (8) (1801-1866), discípulo de Strauss, y Christian Gottlob Wilke (9) (1786-1854) en el año 1838. Según estos autores el evangelio de Marcos no era un resumen de los otros dos, sino el que les había servido de fuente. Esta hipótesis se basaba en la observación de que Mateo y Lucas coinciden entre sí en el orden solo cuando coinciden con Marcos. Weisse postuló además la existencia de una fuente de dichos común a Mateo y a Lucas, poniendo así las bases de la hipótesis de las dos fuentes, que ha determinado el estudio de los evangelios hasta hoy. Según esta teoría, los evangelios de Mateo y Lucas se formaron a partir de dos fuentes: el evangelio de Marcos (10) y una colección de dichos o enseñanzas de Jesús, hoy perdida (11). Únicamente a partir de estas dos fuentes se puede reconstruir la vida de Jesús. Además, hay que admitir algún material propio en Mateo y otro en Lucas (12).

La cuestión planteada por Reimarus y Strauss había calado en algunos teólogos protestantes liberales que aprovecharon el argumento de aquellos para luchar contra el dogma de la Iglesia Católica, el que, según ellos, había deformado la persona y la obra de Jesús, razón esta por la que había que volver la mirada a Jesús antes del dogma. "Liberémonos del dogma y volvamos al hombre Jesús" era la consigna que proclamaban. Lo importante era tratar de alcanzar la personalidad y los rasgos de la religión y la vida interior de Jesús, no el dogma que predicaba la Iglesia Católica. Es esta la llamada escuela liberal que se desarrolla contemporáneamente al racionalis-

(7) Las opiniones de Reimarus y Strauss suscitaron un rechazo generalizado, tanto de católicos como de protestantes, pues, aunque sin eliminar los evangelios, se les vaciaba de todo contenido sobrenatural histórico.

(8) Cf. Ch. H. Weisse, Die evangelische Geschichte, kritisch und philosophisch bearbeitet, 2 vols. Leipzig 1838.

(9) Cf. Ch. G. Wilke, Der Evangelist, oder exegetische-kritische Untersuchung über das Verwandtsverhältnis der drei ersten Evangelien, Dresden/Leipzig 1838.

(10) Los investigadores comienzan a insistir en el valor histórico que hay que dar al evangelio de Marcos. En esta perspectiva son decisivos los aportes de H. J. Holtzmann (1832-1910). Cf. H. J. Holtzmann, Die synoptischen Evangelien. Ihr Ursprung und geschichtlicher Charakter, Leipzig 1863.

(11) Fue Johannes Weiss quien en 1890 dio a esta colección de dichos el nombre de Q (del alemán Quelle=fuente).

(12) La teoría de Weisse y Wilke es finalmente sistematizada por H. J. Holtzmann. 
mo, entre los que sobresalen B. Weiss, A. Harnack y E. Renan (1823-1892) (13), quienes están convencidos de la posibilidad de hacer una vida de Jesús y seguir el desarrollo de su personalidad basados en la crítica literaria de la fuente "Q" y del evangelio de Marcos (14). De alguna manera esta escuela se opone a la escuela racionalista, en cuanto tiene una confianza ilimitada en la historicidad de los evangelios, pero es cierto también que mantiene sus dudas frente a lo sobrenatural narrado en los evangelios.

Se interesaban estos teólogos en trazar el itinerario sicológico de la personalidad de Jesús y liberar su imagen de los retoques del Kerigma de la Iglesia primitiva y del dogma. Pretendían, de esta manera, mediante una "sólida investigación histórica", abrirle al hombre moderno un nuevo acceso a Jesús y una nueva imagen de su persona, que respondiera a las necesidades del hombre. La figura de Jesús que trazan estos exégetas y teólogos es un prototipo de un hombre de la nobleza, de muy altos sentimientos que predica la paternidad de Dios y la fraternidad entre los hombres. La religión predicada por este hombre era una religión interna, moralista, y espiritualizante. El Reino que él anunciaba no era escatológico, sino un reino espiritual y su muerte fue la de un mártir (15).

En 1901 Wilhelm Wrede (16) (1859-1906) publica su tesis sobre el secreto mesiánico en el evangelio de Marcos. Con esa tesis se termina por asestar un golpe mortal y desbaratar el punto de partida de la escuela liberal, que había pretendido elaborar la historia de Jesús a partir de ese evangelio, al que consideraba el más antiguo, base de los evangelios de Mateo y Lucas, y el que, se creía, contenía la figura de Jesús más cercana a la realidad histórica. Wrede pretende demostrar que el evangelio de Marcos es un relato eminentemente teológico, sin ningún interés por la historia. Para él, el secreto mesiánico es una construcción de la comunidad primitiva y no de Jesús. Como este no tenía ninguna conciencia mesiánica, la comunidad primitiva para justificar su actitud postpascual, se encarga de atribuirle el llamado secreto mesiánico, que Marcos retoma en su evangelio, construyendo así una obra teológica y no histórica.

(13) Cf. E. Renan, La vie de Jésus, Paris 1863

(14) Ya H. J. Holtzmann en su obra (ya citada) había colocado en el marco geográfico-biográfico tomado de Mc, que se consideraba histórico, las palabras auténticas de Jesús reconstruidas a partir de la fuente de los logia. Esto significa que se había tomado con bastante seriedad el carácter histórico que se le otorgaba al evangelio de Mc, junto a la idea -apriorística- de que era posible reconstruir el itinerario del desarrollo de la personalidad de Jesús que se veía reflejado en las fuentes.

(15) En 1906 A. SchweITZER, Geschichte der Leben Jesu-Forschung, Tübingen 1906 (La primera parte fue traducida al español hace una década. Cf. SCHWEITZER, Investigación sobre la vida de Jesús, Edicep, Valencia 1990) y, luego, más tarde, J. Jeremías hacen una crítica demoledora a la posición de los teólogos liberales. El primero hace una aguda aguda presentación de las obras publicadas desde Reimarus y demuestra que los autores de las vidas de Jesús habían proyectado sobre él lo que cada uno consideraba el ideal ético supremo. En su intento por liberarse de las ataduras del dogma habían caído en los lazos de las modas filosóficas. El segundo afirma que cada uno de aquellos teólogos proyectaba sobre Jesús sus propios ideales éticos, artísticos y seudocientíficos, colocando en lugar del dogma, la sicología y la fantasía (Cf. J. JeREMIAS, Abba. El mensaje central del Nuevo Testamento, Sígueme, Salamanca 1983, 201).

(16) Cf. W. Wrede, Das Messiasgeheimnis in den Evangelien, zugleich ein Beitrag zum Verständnis des Markusevangeliums, Göttingen 1901. 
La tesis de Wrede, junto a las investigaciones de Karl Ludwig Schmidt (17) (1891-1956), hicieron finalmente colapsar la investigación de la escuela liberal. Este último demostró el carácter fragmentario de los evangelios, señalando que la tradición de Jesús venía dada en pequeñas unidades y que la estructura cronológica y geográfica de la historia de Jesús fue creada luego por el evangelista Marcos. Este dato aportado por Schmidt destruía la posibilidad de seguir el desarrollo de la personalidad de Jesús siguiendo la secuencia de las perícopas como pretendió hacerlo la escuela liberal.

Los trabajos de Wrede y de Schmidt terminan por llevar la investigación sobre la vida de Jesús a un callejón sin salida, pues primero se había descartado el evangelio de Juan como fuente histórica menos fiable (Baur, Strauss), después se había establecido la prioridad de Marcos sobre los otros dos sinópticos (Weisse, Wilke), y ahora se demostraba que también Marcos estaba mediatizado por intereses teológicos y presentaba un carácter muy fragmentario que imposibilitaba conocer la personalidad de Jesús (Schmidt). Termina así este período con una sensación de impasse. De todas maneras algo parecía quedar claro: que a la persona de Jesús solo podría llegarse a través del estudio crítico de los evangelios.

Será Martín Kähler (18) (1835-1912) quien reaccionará fuertemente contra los intentos liberales de reconstruir la vida de Jesús. En una conferencia realizada en el año 1892 bajo el título de "El llamado Jesús histórico y el Cristo de la Biblia" hace Kälher, por primera vez, la distinción entre el Jesús histórico y el Cristo de la fe; distinción que marcaría el nombre y desarrollo posterior de la problemática (19).

Para Kälher, Jesús es el hombre de Nazaret, aquel que es descrito por la investigación crítica, y Cristo es el salvador a quien predica la Iglesia. Para él, el único Jesús real es el Cristo de la predicación y de la fe, no el Jesús del pasado, de quien es poco lo que podemos saber y, además, lo que se pueda saber de él no interesa para la fe. Por esta razón, para Kälher, la investigación de la escuela liberal sobre la vida de Jesús, era inútil. Queda, de esta manera, establecida una separación radical y un abismo infranqueable de discontinuidad entre Jesús de Nazaret y la fe de la Iglesia, entre historia y kerigma.

Viene luego, dentro de esta llamada "antigua investigación" sobre la vida de Jesús un período de radical escepticismo histórico. En el contexto de separación radical entre historia y kerigma, que se venía dando, surge la controvertida figura de Rudolf Bultmann (20) (1884-1976), el teólogo y exégeta protestante de más renom-

(17) Cf. K. L. SCHMIDT, Der Rahmen der Geschichte Jesu. Literarkritische Untersuchungen zur ältesten Jesus-überlieferung, Berlín 1919. (traducción castellana: "La cuestión del marco de la historia de Jesús: historia y principios", en R. AGUIRRE- A. RODRÍGUEZ (eds.), La investigación de los evangelios sinópticos y hechos de los apóstoles en el siglo XX, Estella 1996, 17-35).

(18) Cf. M. KÄHLER, Der sogenannte historische Jesus und der geschichtliche, biblische Christus, Götingen 1882.

(19) La distinción que empieza a hacerse desde M. Kälher entre el Jesús histórico y el Cristo de la fe es más clara en la lengua alemana que en la castellana. En el debate sobre el Jesús histórico los investigadores distinguen entre el objeto de la moderna ciencia historiográfica en la que la historia es concebida como mera verificación de hechos (Historie) y la historia comprendida en cuanto acontecimientos que se interpretan en su significación profunda (Geschichte).

(20) Cf. La obra clásica de R. Bultmann, Das Verhältnis der urchristlichen Christusboschaft zum historischen Jesus, Heidelberg 1960. 
bre en la primera mitad del siglo pasado, quien lleva a su más alto grado de radicalización el programa de Strauss, Kähler y Wrede: la separación entre el Jesús histórico y el Cristo de la fe, centrando toda la importancia en este último.

En ese momento aparecen dos factores que van a contribuir en la dirección que toma la problemática que se viene planteando; ellos son: por una parte, la investigación basada en la escuela de la historia de las religiones y, por otra, la aplicación a los sinópticos del método de la historia de las formas (o crítica de las formas, como suele llamarse recientemente), que $\mathrm{H}$. Gunkel había aplicado con tanto éxito al Antiguo Testamento.

Para la escuela de la historia de las religiones no basta ya con estudiar el peculiar género literario de los evangelios o su interdependencia, sino que el cristianismo se debe considerar y estudiar como un fenómeno religioso entre otros dentro del conjunto de la historia de las religiones, aplicando a su estudio los principios de la fenomenología comparada de la religión. El cristianismo aparece de esta manera como una entre las muchas religiones que proliferaban en el Imperio romano. $\mathrm{R}$. Reitzenstein (21) se puso en la tarea de iluminar con paralelos orientales los orígenes de las creencias helenísticas y, consecuentemente, del cristianismo. Describe Reitzenstein el supuesto proceso de helenización del cristianismo primitivo con tres conclusiones que afectan al estudio del Nuevo Testamento: -la religión helenística y la oriental ejercieron una profunda influencia en la teología del Nuevo Testamento especialmente en la de Pablo; -la proclamación (kerigma) y el culto de la Iglesia primitiva dependen de las religiones mistéricas y del gnosticismo; -la idea del cristianismo primitivo de la redención por la muerte y resurrección de Cristo fue tomada del mito del redentor gnóstico precristiano.

Igual camino siguen los trabajos de W. Bousset (1865-1920), el principal representante de la Escuela de la historia de las religiones en aquel momento. Este autor aplica de una manera sistemática los presupuestos de la escuela de la historia de las religiones, primero al libro del Apocalipsis (22) y, luego, en su obra principal (23), al desarrollo del pensamiento cristiano hasta Ireneo. Según él, Pablo y sus sucesores transformaron el cristianismo primitivo en una religión mistérica. Algunos de los miembros de las comunidades cristianas primitivas habían sido con anterioridad adeptos de religiones de misterios, que ahora adoraban a un dios nuevo, Jesús, como Kyrios, título dado comúnmente al dios-héroe en el culto y ritual de los cultos mistéricos. Bousset a partir de un riguroso análisis de la tradición evangélica llegaba a la conclusión de que había en el cristianismo primitivo dos comunidades con dos concepciones diversas: La palestina que había incorporado a Jesús su concepción judía del Hijo del hombre que habría de venir y la comunidad helenística procedente del paganismo que adoró a Jesús como Kyrios actual, designación que tuvo su origen en el culto litúrgico, por influencia, y como contraposición, de la veneración a divinidades cultuales foráneas.

(21) Cf. R. REITZENSTEIn, Die hellenistischen Mysterienreligionen, ihre Grundgedanken und Wirkungen, Leipzig-Berlín 1910.

(22) Cf. W Bousset, Die Offenbarung Johannis. Neu bearbeitet, Gotinga 1896.

(23) Cf. W. Bousset, Kyrios Khristos. Geschichte des Christusglaubens von den Anfängen des Christentums bis Irenaeus, Gotinga 1913 
Dentro de esta misma escuela, J. Wellhausen, investigador dedicado principalmente al Antiguo Testamento, pero que también dedicó alguno de sus estudios al Nuevo Testamento, radicalizó la crítica histórica aplicada a los evangelios. Según Wellhausen, el título de "Hijo del hombre" significaba en boca de Jesús simplemente "hombre". Después de su muerte y resurrección la comunidad primitiva transformó el apelativo en un título mesiánico y se le otorgó una filiación divina real. Los primeros cristianos acabaron de transformar la imagen del Jesús terreno, uniendo su persona con las concepciones escatológicas de la época (24). Para este mismo autor, los evangelios no tienen ningún valor como fuente para la historia de Jesús, sino como testimonio de la fe de la comunidad cristiana primitiva. La múltiple tradición evangélica se plasmó en los evangelios según el orden creado por los evangelistas. Jesús no fue cristiano sino judío, ya que pertenecía teológicamente al judaísmo puesto que el cristianismo solo comienza con la pascua (25). Será más tarde R. Bultmann quien saque la consecuencia de estos estudios: por una parte, es necesario desmitologizar los escritos del Nuevo Testamento que han sido helenizados bajo el influjo de las religiones mistéricas, y por otra parte, la enseñanza de Jesús no es relevante para una teología cristiana puesto que Él es un judío y el cristianismo solo arranca después de pascua.

El otro factor que mencionábamos es la aplicación al Nuevo Testamento del método exegético llamado "historia de las formas" (en alemán Formgeschichte = FG), del que Martín Dibelius (26) y Rudolf Bultmann (27) eran maestros y el cual aplican en la hermenéutica del Nuevo Testamento. La FG quiere responder al vacío dejado por la crítica literaria en el estudio del N.T., pues la teoría de las dos fuentes, Marcos y "Q" como origen de los otros evangelios, deja sin resolver la pregunta sobre qué había antes de Marcos y "Q". Bultmann y su escuela ayudados por dicha metodología se ponen en la tarea de estudiar la historia de la tradición evangélica.

Ya K. L. Schmidt había descubierto que los evangelios habían sido compuestos a partir de pequeñas unidades independientes y que el marco narrativo fue creado secundariamente por los evangelistas. Ahora la escuela de la historia de las formas intentan mostrar que esas pequeñas unidades literarias estaban impregnadas de la fe comunitaria, pues se habían transmitido en diversos contextos de la vida eclesial. Este descubrimiento colocó la investigación sobre los evangelios en un lugar diverso al que se venía haciendo. Se pasó del estudio de las fuentes, como se hacía en la etapa anterior, al estudio de las tradiciones. Así fue apareciendo claro un período hasta ahora desconocido en la formación de los evangelios: el que va desde la pascua hasta la elaboración de las fuentes más antiguas. Es en este periodo que las tradiciones sobre Jesús se van concretando en pequeñas formas literarias, que llamamos perícopas, a través de las cuales la tradición se va homogenizando y conservando. Quien quisiera, entonces, acercarse a los evangelios tenía que conocer la historia de la tradición.

(24) Cf. J. WellhaUSEN, Israelitische und jüdische Geschichte, Berlín 1894.

(25) Cf. J. Wellhausen, Einleitung in die drei ersten Evangelien -Introducción a los tres primeros evangelios-, Berlín 1905.

(26) Cf. M. DiBelius Die Formgeschichte des Evangeliums, Tubinga 51966.

(27) Cf. R. Bultmann, Die Geschichte der synoptischen Tradition, Gotinga 61964. 
Para la escuela Bultmanniana la gran mayoría de estas unidades de la tradición oral no se originaron durante la vida de Jesús, sino que habría que situarlas en la vida misma de las comunidades que las transmitieron, que es el lugar en el que propiamente tuvieron su origen precisamente para responder a diversas necesidades comunitarias. Como pocas o ninguna de esas unidades de tradición oral habían tenido su origen en el contexto de la vida de Jesús es imposible reconstruir su vida, termina diciendo esta escuela.

Concluye, entonces, la escuela de la historia de las formas que:

- los evangelios no son biografías sino testimonios de fe para las exigencias de evangelización de las diversas comunidades;

- $\quad$ ellos no son composiciones debidas a una persona, sino que son compilaciones de pequeñas unidades literarias a las que es posible seguirles su recorrido antes de ser organizadas en los evangelios.

- $\quad$ El trabajo primordial del investigador es llegar a reconstruir el ambiente vital originario de las perícopas (Sitz im leben), que es el lugar en el que el recuento evangélico adquiere su significación plena para llegar de este modo no al Jesús de la historia, sino al contexto de la comunidad en que se originaron.

Aplicando esta metodología, y bajo tres factores de influencia -las conclusiones de la escuela de la historia de las religiones que ya hemos mencionado; los postulados de la teología dialéctica que fundamenta la fe en la predicación y no en la historia reivindicando la primacía de la sola fides frente a la razón o a cualquier tipo de evidencia histórica; los presupuestos filosóficos existencialistas de Martín Heidegger, quien fuera su maestro-, es como Bultmann elabora sus trabajo investigativo. Para él el fundamento del cristianismo no es Jesús, ni lo que él hizo o dijo, sino la predicación de la comunidad primitiva. Es ella la fuente del Kerigma y la que crea el mito de Jesús como Señor que provoca su divinización según la cultura helenista y la tradición apocalíptica. El kerigma no nació de la vida de Jesús sino que más bien es la vida de Jesús la que es iluminada por el kerigma y es este quien le da un sentido a aquella.

Por eso es imposible pretender reconstruir la vida de Jesús, pues de él no podemos saber nada porque todo está impregnado de la fe de la comunidad, y en caso de que pudiéramos saber algo, no sería relevante para la fe, pues Jesús pertenece al ámbito del judaísmo, no del cristianismo y en este, desde el comienzo, la fe no consiste en la existencia y afirmación de hechos objetivos, sino en la respuesta a la palabra proclamada que interpela al hombre y le brinda el sentido de su existencia. Al Nuevo Testamento hay que ir, por tanto, despojándolo de su ropaje mítico (desmitización) y preguntando qué representa el kerigma en el aquí y ahora de mi vida (interpretación existencial).

Para Bultmann, Jesús existió realmente y está a la base del movimiento histórico desatado en la comunidad primitiva, pero él es solo una mera ocasión extrínseca de la que Dios se vale: doctrinalmene no reveló nada y la salvación se da a pesar de él. Por eso él no es decisivo para la fe. En el fondo del kerigma primitivo, mediante un ropaje mítico (milagros, resurrección, hijo del hombre, hijo de Dios, etc.), que es necesario interpretar, lo que se quiere afirmar es que en Jesús nos ha llegado la 
interpelación definitiva y última por parte de Dios que nos invita a una decisión de fe, también definitiva y última, en favor de Dios o del mundo caduco (28).

\section{LA “NUEVA INVESTIGACIÓN”-LA NEW QUEST-SOBRE JESÚS (1953-1980)}

La posición asumida por Bultmann crea una reacción entre sus mismos discípulos, a la vez que ocasiona el estudio del problema por parte de los teólogos católicos. Se puede decir que todos los teólogos y exégetas postbultmanianos buscan de nuevo al Jesús histórico, no prescindiendo del kerigma, sino a partir del kerigma mismo.

La "nueva pregunta por el Jesús histórico" es originada por Ernst Käsemann (29), discípulo directo de Bultmann, quien da un nuevo rumbo a la problemática a partir de una conferencia pronunciada el 20 de octubre de 1953 en la que reacciona contra la posición de su maestro. Según Käsemann la vida del Jesús terreno es de suma importancia para la fe. La vida del Jesús de la historia forma parte de la fe cristiana, porque el Señor terreno y el exaltado es el mismo. La fe de pascua es la fundamentación del kerigma pascual, pero no la primera y única fuente de su contenido. Aquella tuvo que integrar la vida de Jesús en el kerigma anunciado. De ahí que la investigación del Jesús de la historia sea teológicamente legítima y posible y por ello hay que realizar una investigación a partir de los evangelios que lleve a constatar la continuidad entre la predicación de Jesús y la de los apóstoles, pues "de la oscuridad de la historia de Jesús brotan ciertos rasgos característicos de su predicación, perceptibles con relativa exactitud, asociados por el cristianismo a su propio mensaje" (30).

En este mismo sentido se inscribe la importante obra cristológica de G. Bornkamm, Jesús de Nazaret, publicada en 1956 (31), discípulo de Bultmann, sucesor de Dibelius y profesor en Heidelberg, quien pone el acento de su búsqueda en los hechos de Jesús y el impacto que su personalidad produjo en su entorno, y los trabajos de H. Conzelmann (32), W. Marxen (33) y de los representantes de la

(28) Jesús murió en la cruz sin haber pretendido ser el Mesías o el hijo del hombre o de haber realizado históricamente algún milagro (Cf. R. Bultmann, Jésus, Paris 1968, 35ss). Por eso el predicador no interesa nada para la fe, ni su mensaje ni sus acciones ni sus enseñanzas ni tampoco los sucesos de su vida: su nacimiento, su pasión y su muerte en cruz. Todo esto no tiene ninguna relevancia teológica. Lo verdaderamente importante es la revelación que proporciona el kerigma: que en la fe el hombre logra una autocomprensión de su existencia que le posibilita realizarse de una manera auténtica (Cf. R. BultMAnN, Creer y comprender, Madrid 1974, 97 y 251). Esta es la razón por la que Bultmann en su monumental obra sobre la Teología del Nuevo Testamento solo dedica un corto espacio a la vida de Jesús.

(29) Cf. A Käsemann se debe la expresión New Quest y el nuevo rumbo que toma la investigación. Cf. E. KäSEMAnn, El problema del Jesús histórico, en E. KäSEMAnn, Ensayos exegéticos, Sígueme, Salamanca 1978, 159-189.

(30) IBID., 169.

(31) G. BornKamm, Jesús de Nazaret, Sígueme, Salamanca 1982.

(32) Cf. H. Conzelmann, Grundriss der Theologie des Neuen Testaments, Tubinga 1967.

(33) Cf. W. MARXEN, Zur Frage nach dem historischen Jesús en Theologische Literaturzeitung 87 (1962) 575-580. 
llamada "Nueva hermenéutica": E. Fuchs (34), G. Ebeling (35), J. M. Robinson (36) y H. Braun (37), para quienes la persona de Jesús es la legitimación y el fundamento del kerigma y no es posible afirmar nada de Jesús en una perspectiva cristológica que no se base en el propio Jesús histórico.

De capital importancia son los estudios realizados por J. Jeremias (38), que por los años cincuenta, es quien más diametralmente se opone a Bultmann. Propugna este exégeta un movimiento de retorno al Jesús de la historia y proclama que la base para una cristología históricamente cimentada no puede ser otra sino las auténticas palabras y hechos de Jesús (ipsissima verba et facta Jesu). El comienzo de la fe no está en el kerigma, sino en el hecho histórico de la vida de Jesús. La vuelta al Jesús de la historia es necesaria no solo por fidelidad a las fuentes, sino porque el kerigma predica que Dios reconcilió al mundo con él por medio de un acontecimiento histórico. Según Jeremias, no se puede separar la historia del kerigma a riesgo de caer en el ebionismo o en el docetismo.

A partir de ese momento las reacciones se siguen en cadena y todas tendentes a mostrar que la tradición y los evangelistas sí se interesan y poseen en su interior elementos históricos que fueron celosa y fielmente consignados en los evangelios. En 1957 H. Riesenfeld (39) hace una conferencia en Oxford sobre los cuatro evangelios, orientada a demostrar que en tiempos de Jesús en Palestina había la costumbre de transmitir algunos dichos, sobre todo de los rabinos, lo que de alguna manera posibilita pensar que los dichos de Jesús fueron guardados y transmitidos por sus discípulos y que, luego, las comunidades y los evangelistas reciben. Luego, en 1961, su discípulo B. Gerhardsson (40) elabora una tesis en la que muestra como en el Talmud se transmiten los dichos rabínicos, que muchas veces tienen su origen hasta tres generaciones atrás y que son sintetizados y aplicados a los nuevos tiempos que vive Israel. Concluye este autor, que si a Jesús lo llamaban Rabí era porque enseñaba como un rabí y que sus discípulos transmitieron sus dichos según las estrictas normas de la "memorización" y la "conservación inalterable" propias de la pedagogía rabínica en la trasmisión de la Torá, que el mismo Jesús debió enseñarles. Estos dichos fueron luego actualizados para las diversas necesidades de la Iglesia naciente.

En la misma perspectiva anterior, el teólogo y exégeta católico Heinz Schürmann, con la ayuda del método de la historia de las formas trata de llegar, no solo hasta la historia de la tradición en sus formas literarias, sino que intenta un acceso a la vida de Jesús y los comienzos prepascuales de la tradición de los logia (41). Se pregunta él ¿por qué razón -como pensaba Bultmann- la Iglesia creó los dichos y

(34) Cf. E. Fuchs, Zur Frage nach dem historischen Jesús, Tübingen 1960.

(35) Cf. G. Ebeling, Das Wesen des christlichen Glaubens, Tübingen 1959

(36) Cf. J. M. Robinson, A New quest of the historical Jesus, London 1959

(37) Cf. H. Braun, Der Mann aus Nazareth und seine Zei, Stuttgart 1969; trad. Castellana: El hombre de Nazaret y su tiempo, Salamanca 1975.

(38) Cf. J. Jeremias, Das Problem der historischen Jesus 1960; Abba. El mensaje central del Nuevo Testamento, Sígueme, Salamanca 1972.

(39) Cf. H. RIESENFELD, The Gospel tradition, Oxford 1970.

(40) Cf. B. Gerhardsson, Memory and manuscript. Oral tradition and written transmission in rabbinic Judaism and early christianity, Uppsala 1961

(41) H. SChÜRMAnN, La tradizione dei detti di Gesù, Brescia 1985. 
los puso en boca de Jesús para satisfacer sus necesidades postpascuales? ¿Acaso no puede haber un Sitz im Leben prepascual? Schürmann piensa que sí es posible alcanzar un ambiente prepascual de algunos dichos de Jesús, que sus discípulos conservan en su memoria y que luego pudieron ser aplicados a las necesidades de las nuevas situaciones y acomodados a la situación de la Iglesia (42).

Es de anotar que ayudó mucho a la reacción contra la posición de Bultmann, la aparición en el campo de la exégesis de la Redaktionsgeschichte (RG) que, junto con los nuevos presupuestos hermenéuticos que estaban apareciendo, ayuda a precisar algunas cuestiones pendientes dejadas por el uso de la metodología de la historia de las formas. La exagerada ruptura que esta establecía entre el Jesús de la historia y el Cristo de la fe; el demasiado énfasis que se ponía en la fuerza creadora de la comunidad eclesial, y el desconocimiento o poca importancia que se le daba a los evangelistas en su tarea redaccional son ahora temáticas que se abordan desde una nueva perspectiva. La investigación se centra en este momento en averiguar la naturaleza y el grado de continuidad que une a la comunidad prepascual con la postpascual, la conciencia que la primitiva comunidad tenía de su relación y fidelidad histórica con Jesús y, por último, el reconocimiento de que los evangelistas no son meros ensambladores de formas literarias sino que tienen un papel teológico importante en la composición de los evangelios.

En este momento de la investigación, y superando así el escepticismo bultmanniano, se van también fijando los llamados "criterios de autenticidad histórica" (43), que permiten orientar con un mayor rigor la búsqueda de Jesús, pues a partir de su aplicación a los textos evangélicos se distingue qué procede del propio Jesús y qué de la comunidad postpascual. Dichos criterios se han considerado, unos como fundamentales y otros como secundarios. Se consideran fundamentales aquellos que tienen un valor propio y autorizan un juicio cierto de autenticidad; son cuatro: 1 . criterio de testimonio múltiple, por el que se considera como auténtico un dato que esté sólidamente atestiguado en todas las fuentes -o en la mayor parte de ellas- de los evangelios u otros escritos del N.T. Este es un criterio fundamental cuando se trata de reconocer los rasgos esenciales de la figura de Jesús, su predicación y su actividad; 2. Criterio de discontinuidad por el que se considera auténtico un dato evangélico cuando no puede reducirse a las concepciones del judaísmo o a las concepciones de la Iglesia primitiva. El uso de este criterio permite encontrar muchos textos auténticos en su forma y en su contenido; 3. Criterio de dificultad, que considera auténtico cualquier dicho o acción de Jesús que haya creado dificultad o desconcertado a la Iglesia primitiva, pues no es fácil pensar que ella se hubiera inventado algún material que la dejara en una posición difícil frente a sus oponentes; 4. Criterio de coherencia según el cual se considera como auténticos hechos y di-

(42) Además de los nombres ya mencionados son importantes en el campo protestante, los trabajos de H. Braun y, más recientemente, de W. Pannenberg y J. Moltmann. En el campo católico hay que mencionar a F. Mussner, A. Wickenhauser, K. H. Schelker, K. Rahner, X. L. Dufour, R. Marlé, I. de la Potterie, J. Caba,, E. Schillebeeckx, Ch. Duquoc, H. Küng, W. Kasper, J. I. González Fauss, R. Latourelle, R. Fabris, F. Lambiasi, B. Forte, entre otros.

(43) Una relación del estado de la cuestión hasta finales de los años setenta se encuentra en R. LAtourelle, A Jesús el Cristo por los Evangelios, Sígueme, Salamanca 1982, 202-226. 
chos de Jesús que encajen bien en la "base de datos" preliminar establecida mediante la aplicación de los otros criterios.

El criterio al que más fuerza se le da es al llamado criterio de discontinuidad o desemejanza a partir del cual se tiene como histórico en Jesús lo que está en discontinuidad con el mundo judío de su tiempo y que no es recogido por la Iglesia posterior. Este criterio permite captar la diferencia y originalidad de Jesús frente al judaísmo de su época.

Ayudados por toda le metodología investigativa de la crítica histórica la New Quest quiere dar respuesta a importantes interrogantes: si historia y sentido están estrechamente ligados, ¿es posible distinguirlos - no separarlos- de tal manera que tengamos acceso a la historia humana de Jesús? Y a continuación vienen otros interrogantes: ¿En qué sentido son, entonces, los evangelios obras históricas? ¿Cómo maneja la tradición y los evangelistas, la historia humana de Jesús? ¿Son ellos fieles a esa historia? ¿Cómo se debe colocar un investigador frente a los evangelios? Con el afán de responder a estos interrogantes y con base en los criterios de autenticidad histórica se trazan los rasgos más sobresalientes de la personalidad y el proyecto de vida de Jesús. La crítica literaria da paso aquí a la crítica histórica. La investigación se preocupa por mostrar que la fidelidad de los evangelios se da no solo en la transmisión de los dichos y gestos de Jesús, sino que también pertenece al orden mismo de los hechos y que es posible verificarla.

El interés por responder los interrogantes enunciados hace que la preocupación de los investigadores se centre en un punto para ellos decisivo: el lugar en el que se entrelazan la persona y la enseñanza de Jesús y el kerigma apostólico. Se trata de resolver la cuestión entre la historia y la fe. Para su solución recurren al concepto de "cristología implícita" (44), según el cual todo lo que la fe pascual desarrolló estaba ya contenido implícitamente en la persona, acciones, enseñanza y pretensiones de Jesús. Al lado de este interés aparece otro, ya mencionado: la fuerza que se hace en la originalidad y discontinuidad de Jesús frente al judaísmo de su época y a las creencias mismas de la comunidad primitiva. Esta originalidad y ruptura de Jesús frente al judaísmo justifica el impacto y novedad con la que la fe postpascual presentó a Jesús, que si bien se ubicaba dentro de las promesas veterotestamentarias las rebasaba de un modo tal, que su figura fue alcanzando unos ribetes reveladores nuevos y de ahí las expresiones originales y culmen de la fe neotestamentaria. La claridad lograda en estos dos elementos, que frente a la Old Quest constituían una fortaleza y una ganancia, tanto en el ámbito histórico como teológico, terminó constituyéndose en la fragilidad de esta investigación y en la causa de su pronto envejecimiento, pues lo primero ocasionó que la investigación se estancará y lo segundo terminó por divorciar a Jesús de su ambiente judío y de las realidades políticas, sociales, culturales, económicas y hasta religiosas de su tiempo.

De todas maneras la New Quest alcanzó unas ciertas claridades en el proceso investigativo que ya se consideran logros y adquisiciones comunes para todos los que de ahora en adelante quieran buscar la historia original de Jesús:

(44) Fue H. Conzelmann el primero en usar esta expresión. 
- $\quad$ Es imposible, y además innecesario, hacer una biografía de Jesús en el sentido moderno de la palabra.

- Los evangelios son las únicas fuentes de acceso a Jesús y en ellos están unidos acontecimiento histórico y sentido a la luz de Pascua. El Jesús histórico no es separable del Cristo de la fe y el único camino de acceso posible son los evangelios y, en ellos, es imposible separar acontecimiento e interpretación, historia y fe. Por esta razón la búsqueda del Jesús histórico se hace siempre en y a través del kerigma.

- Hay una continuidad histórica y teológica entre el Jesús histórico y el Cristo de la fe. El Jesús histórico ha sido kerigmatizado y el kerigma hace referencia a la historia concreta de Jesús.

- Al origen de toda la tradición primitiva está Jesús.

- No hay cristología sin un conocimiento de la persona y obra de Jesús y este conocimiento es posible y realizable.

- Se busca no una mera información sobre Jesús, sino su significación existencial para la comprensión del misterio humano.

\section{LA “TERCERA INVESTIGACIÓN” -LA THIRD QUEST-SOBRE JESÚS $(1980 \ldots)$}

Aunque no es fácil identificar los orígenes de lo que se viene conociendo hoy con el nombre de Third Quest (45), se podría decir que entre1965 y 1975 se comienzan a enunciar los temas de discusión que con mayor claridad aparecerán a partir de 1980, fecha en que se considera que propiamente empieza este tipo de investigación. Tampoco es fácil encontrar unas características comunes y compartidas de manera absoluta por todos los autores que se inscriben dentro de este horizonte investigativo ni tampoco se puede decir que todos los que hoy investigan sobre Jesús puedan clasificarse dentro de él.

De entrada es posible resaltar tres elementos significativos que configuran esta investigación: 1. El desplazamiento del mundo alemán, lugar en el que privilegiadamente se hicieron las grandes investigaciones sobre Jesús en los dos siglos anteriores, al mundo anglosajón; 2. El trabajo investigativo no se realiza ya en instituciones teológicas sino profanas y con un carácter netamente interdisciplinario en el que participan no solo exegetas y teólogos, sino también historiadores, sociólogos, arqueólogos y antropólogos; además de interdisciplinar, la nueva búsqueda se ha vuelto interconfesional, interreligiosa, e internacional; 3. Es tal la producción actual de obras sobre Jesús que bien se puede afirmar que en ninguna otra época se han escrito tantas y tan importantes obras sobre él como en este tiempo.

De todas maneras esta tercera búsqueda se presenta con características marcadamente diversas de la New Quest, entre las que se pueden señalar las siguientes:

(45) El término Third Quest fue concebido por S. NEIL TOM WRIGHT, The Interpretation of the New Testament 1861-1986, University Press, Oxford 1988, 379-403. Ver, también, S. NEIL ToM WRIGHT, Jesus and the Victory of God, London 1996, 1-144. 
- El reconocimiento de que los cuatro evangelios canónicos -sobre todo los sinópticos- son las principales fuentes históricas que poseemos sobre Jesús. A ellos se les concede un cierto grado de credibilidad histórica y se consideran una plataforma válida para acceder al Jesús de la historia.

- La importancia decisiva que se le concede a la fuente Q (46) y la valoración sin restricciones de la literatura apócrifa, tanto judía como cristiana, los targumes y los documentos de Qumran y Nag Hammadi (Alto Egipto). En este contexto se da un papel decisivo al llamado Evangelio de Tomás (47).

- El diálogo con otras ciencias como la arqueología, la papirología, la literatura, la antropología cultural, las ciencias de la religión, y las ciencias sociales en general.

- La plena colocación de Jesús en el ambiente y el contexto sociohistórico judío de su época, sobre todo, la situación de la Galilea, en la que se desarrolló un judaísmo diferente al de Jerusalén, con un notable influjo del helenismo y un importante proceso de urbanización que causó tensiones con las formas tradicionales de vida. Se piensa que conociendo la realidad social de Galilea se conoce a Jesús (48). En este contexto se revalúa la criteriología de autenticidad histórica, sobre todo, el criterio de discontinuidad con el ambiente judío al que tanta importancia le daba la New Quest. Se considera que Jesús no es un "extraño" a su ambiente, sino que más bien, está completamente inserto en él.

(46) Algunos de los autores de esta corriente consideran la fuente Q una fuente privilegiada para conocer históricamente a Jesús. En sus estudios han encontrado en ella al menos dos estratos, que representan diferentes momentos en el desarrollo de la comunidad cristiana de Palestina. El primero de estos estratos, más cercano al Jesús de la historia, está compuesto de enseñanzas de tipo sapiencial que muestra la figura de un Jesús sabio; el segundo, es más de tipo apocalíptico. Incluso se llega a afirmar que el Jesús original es el sapiencial y que los rasgos apocalípticos son ya elaboración de la comunidad. Sobre este tema, ver J. S. KLOPPENBORG, The Formation of $Q$ : Trajectories in Ancient Wisdom Colecctions, Philadelphia 1987.

(47) Se trata de un manuscrito copto del siglo III-IV y que contiene una colección de ciento catorce dichos "secretos" de Jesús escritos por Dídimo Judas Tomás, discípulo del Señor. Son diálogos cortos y sin ninguna conexión narrativa. Es claro que el término evangelio atribuido a este escrito no se refiere a su género. Se puede decir que se parece más a la fuente "Q". Se ha descubierto que aproximadamente el $40 \%$ del contenido de este texto se encuentra en Q. Para una evaluación de este manuscrito y de otros encontrados en Nag Hammadi, ver J. MEIER, o. c., 131-182. Sin embargo, Meier rechaza el uso del material apócrifo para la reconstrucción del Jesús histórico. Para una valoración positiva de los apócrifos del Nuevo Testamento, ver H. KoEsTER, Introduction to the New Testament, I-II, Fortress, Philadelphia 1989.

(48) Entre los autores de la Third Quest que más han destacado la importancia de Jesús dentro de las circunstancias económicas, sociales y políticas de la Galilea de aquel momento y relacionándolo, no con las elites religiosas, sino con el ambiente campesino popular, sobresalen: R. A. HoRSLEY, Galilee: History, Politics, People, Valley Forge 1996; ID., Jesus and Spiral Violence, Harper and Row, San Francisco 1987; ID., Sociology and the Jesus Movement, Crossroad, New York 1989; R. A. Horsley-J. S. HAnson, Bandits, Prophets and Messiahs: Popular Movements of the Time of Jesus, Minneapolis 1985; G. THEISSEN, Estudios de sociología del cristianismo primitivo, Sígueme, Salamanca 1985; ID., The Shadow of the Galilean: The Quest for the Historical Jesus in Narrative Form, Fortress Press, Philadelphia 1987; ID., The Gospels in Context: Social and Political History in the Synoptic Tradition, Fortress Press, Minneapolis 1991; C. A. Evans, Jesus and His Contemporaries, New York 1995; S. FREYNE, Galilee from Alexander the Great to Hadrian. A Study of second Temple Judaism, Wilmington 1980; ID., Galilee, Jesus and The Gospel: Literary Approaches and Historical Investigations, Dublin 1988; ID., The Geography, Politics, and Economics of Galilee and the quest for the historical Jesus en B. CHILTON- A. Evans (EDS.), Studying the Historical Jesus: Evaluations of the State of Current Research, Leiden 1994, 75-122. 
- La búsqueda de Jesús se centra casi que en lo puramente histórico e interdiciplinar, y por eso el uso cada vez más riguroso de la metodología sobre todo histórica (49) y, a veces, sociológica (50) y antropológico-cultural (51), dejando a la sombra, aunque no desconociendo, cualquier preocupación teológica-hermenéutica, y esto hasta tal punto que ya muy poco se plantea el problema de la relación entre el Jesús histórico y el Cristo de la fe. Lo que interesa propiamente es rescatar la imagen de Jesús de y para la historia (52).

- Un interés sociológico más que teológico. Las tensiones características de la sociedad judía del primer siglo se reflejan en la aparición y en el destino de Jesús y es posible encontrar, según estos investigadores, una continuidad social entre el círculo prepascual en torno a Jesús y el cristianismo después de Pascua.

De la lectura global de las principales obras que se publican en torno a Jesús dentro de la Third Quest es posible sacar a la luz algunas cuestiones que son las que ocupan el centro de interés de estos investigadores y que todavía no han encontrado una clarificación precisa:

- En lo que respecta a la metodología dos temas son relevantes para la Third Quest: por una parte, el de la importancia que se debe conceder a la literatura apócrifa y, por otra, el de los criterios de autenticidad histórica y su uso. En estos dos aspectos pareciera que cada investigador siguiera su propio camino.

- Los datos aportados por las ciencias sociales son también valorados y utilizados de muy diversa manera. En este campo la relación de Jesús con el contexto sociohistórico de su tiempo es otro foco de discusión. Unos piensan que la Galilea de aquel momento era conflictiva y que en esa situación Jesús se presenta como un reformador social (Borg, Crossan, Horsley). Otros piensan que la situación de Galilea era tranquila y pacífica y que Jesús se comportaba como un profeta escatológico que anuncia el fin del mundo para el tiempo futuro y sin ningún interés por la realidad social (Sanders, Meier).

- $\quad$ Otra de las grandes cuestiones de la Third Quest es la relación de Jesús con el judaísmo. Si bien es cierto que en la época de Jesús había una importante influencia griega, sobre todo en Galilea, parece ser que no es posible pensar que la mayor influencia de Jesús sea el mundo griego y no el judío. Lo importante en esta cuestión es aclarar cuál es el tipo de relación que Jesús establece

(49) Aquí se ubica la obra de Meier ya citada. Además, es importante la obra de L. T. JoHnSON, The Real Jesus, Harper Collins, San Francisco 1996.

(50) Cf. Las obras ya citadas de G. Theissen; además: G. TheIssen - A. MERZ, El Jesús histórico, Sígueme, Salamanca 1999.

(51) Este es el telón de fondo de la obra de B. J. MALinA, El mundo del Nuevo Testamento, Estella 1995.

(52) Si bien es cierto que la aproximación a Jesús con parámetros puramente históricos e interdisciplinares es una novedad que aporta matices muy serios y rigurosos a la investigación, también es cierto que aquí puede estar una de las debilidades de la forma y metodología de investigación de la Third Quest, pues colocar la fe al margen para hacer una reconstrucción pretendidamente neutral es, de alguna manera, ambicionar colocarse al margen del misterio de Jesús, y pretender eso en el caso de Jesús es, de alguna manera, incapacitarse para acceder y comprender plenamente su historia. 
con el judaísmo. Algunos de los investigadores de la Third Quest judaízan a Jesús hasta el punto de negar cualquier conflictividad con el mundo judío, sin embargo, la originalidad de Jesús, que crea un serio conflicto con las autoridades judías y que lo lleva a la muerte, no se puede desconocer. Los autores divergen en sus posiciones respecto a la naturaleza de esa conflictividad desencadenada por Jesús.

- Una última cuestión es la relación recíproca entre la comprensión del Reino de Dios y la idea que se tiene del Jesús histórico. La discusión empezada hace ya un siglo acerca del carácter presente o futuro que Jesús le daba en su predicación a la llegada del Reino es un tema que ocupa también, de una manera especial, el interés de la Third Quest, aunque con matices diversos. Muchos autores piensan que los dichos acerca del reino de Dios futuro son creación de la comunidad. Sin embargo, parece que la inminencia, o al menos la cercanía, del reino de Dios hace parte de la predicación de Jesús. El problema es clarificar qué importancia tuvo esta dimensión y si la irrupción futura del reino suponía el final cercano de la historia (Sanders, Meier) o más bien una transformación social en el momento presente (Crossan, Mack), o también hay la posibilidad de pensar que Jesús se refería a un reino futuro, entendido como una transformación de la historia, pero que no la suprime. Los que piensan esto último ven a Jesús como un profeta social que no excluye su carácter también escatológico. De todas maneras la forma de entender la escatología de Jesús está muy relacionada con la forma de comprender la incidencia histórica de su proyecto.

- De la diversidad de aproximaciones que estos autores hacen al Jesús histórico van emergiendo rasgos nuevos de la persona de Jesús (53): algunos subrayan el aspecto campesino, sapiencial (54) y social-reformador (55), otros el aspecto

(53) Una descripción de los aportes de sus más significativos representantes se encuentra en $R$. AGUIRRE, Estado actual de los estudios sobre el Jesús histórico después de Bultmann, en "Estudios Bíblicos” 54 (1996) 433-463. También en J. PELÁEZ, Un largo viaje hacia el Jesús de la historia, en J. J. TAmayo, Diez Palabras sobre Jesús de Nazaret, Ed. Verbo Divino, Estella: Navarra 1999, pp. 57-123; E. VALLAURI, "Volti di Gesù negli studi più recenti", Laurentianum, 39 (1998) 293337; S. FREYNE, "La 'terza'ricerca sul Gesù storico. Alcune reflessioni teologiche”, Concilium 32 (1997) 60-79; J. M. BoRG, Jesus in Contemporary Scholarship, Valley Forge 1994; D.C. ALLISON, "The Contemporary Quest for the Historical Jesus", IrBibSt 18 (1996) 174-193; M. E. BoRING, “The 'third Quest' and the Apostolic Faith, Interpretation 50 (1996) 341-354.

(54) La figura de Jesús comprendida como la de un sabio, inscrito en el contexto de la sabiduría de Dios, aparece en: E. S. FIOREnZA, In Memory of Her: A Feminist Theological Reconstruction os Christian Origins, Crossroad, New York 1984; ID., Miriam's Child, Sophia's Prophet: Critical Issues in Feminist Christology, Continuum, New York 1994.; B. WiTHERINGTON III, Jesús the Sage: The Pilgrimage of Wisdom, Fortress Press, Minneapolis 1994.

(55) Cf. Comprenden a Jesús como un profeta reformador social G. Theissen (Cf. Obras citadas), R. A. Horsley (Cf. Obras citadas) y J. D. CRossan, Jesús: vida de un campesino judío, Crítica, Barcelona 1994; ID., Jesús: Biografía revolucionaria, Crítica, Barcelona 1996; ID., Historical Jesus as Risen Lord, Trinity Press, Valley Forge 1999; ID., The birth of Christianity, Harper, San Francisco 1998; ID., The Essential Jesus, Harper Collins, San Francisco, 1995; ID., The Jesus Controversy. Perspectives in Conflict, Trinity Press, Valley Forge 1999. Crossan considera a Jesús como un cínico al estilo de los filósofos cínicos, pero resaltando su carácter de campesino judío. Otros que insertan a Jesús dentro de esa corriente helenista son: B. L. MACK, A Myth of Innocence: Mark and Christian Origins, Fortress Press, Philadelphia 1988; F. G. DownING, Jesus and the Threat of Freedom, London 1987; ID., Christ and the Cynics: Jesus and Other Radical Preachers in First Century tradition, Sheffield 1988. 
hebreo (56), otros su carácter de exorcista (57), otros el carácter proféticosocial, sapiencial y no mesiánico-escatológico (58), otros el carácter marginal y escatológico de la figura de Jesús (59). De todas maneras y en términos generales, aunque no todos los autores, al menos de las obras de la mayoría la figura de Jesús que se desprende es la un maestro de sabiduría no apocalíptico, que no se tuvo por Dios; que anunció el reinado de Dios como una realidad para el presente y no para el futuro y que vivía y enseñaba formas subversivas de comportamiento frente al mundo judío de su época (60).

Dentro de esta "tercera búsqueda" del Jesús histórico hay que hacer notar el trabajo y los aportes de dos importantes grupos de investigadores. Se trata, por una parte, de un grupo de estudiosos de diversas disciplinas que han constituido un seminario permanente sobre Jesús, que se ha denominado "Jesus Seminar", y por otra, de otro grupo que se ha interesado por estudiar y mostrar el carácter "biográfico" que poseen los evangelios, al estilo de las grandes biografías de la antigüedad grecorromana.

\section{El “Jesus Seminar”}

Es un colectivo no confesional de estudiosos norteamericanos, constituido en 1985 por algo más de 70 exégetas e historiadores, dedicados a determinar la autenticidad histórica de los dichos y hechos de Jesús y hacer conocer de la opinión pública el resultado de sus investigaciones (61). Su sede es en Sonoma (California) y sus directores son: Robert W. Funk y John Dominic Crossan.

(56) Cf. G. Vermes, Jesús, el judio, Barcelona 1977; ID., Jesus and the World of Judaism, London 1983; ID., La religión de Jesús el judio, Barcelona 1995.

(57) Cf. G. H. TwelftreE, Jesus the Exorcist, Tübingen 1993.

(58) Cf. M. Borg, Conflict, Holiness and Politics in the Teachings of Jesus, New York-Toronto 1984; ID., Jesús. A New Vision, Harper and Row, San Francisco 1987; ID., Meeting Jesus Again for the first Time, Harper and Row, San Francisco 1994; ID., Jesus in Contemporary Scholarship, Trinity International Press, Valley Forge 1994; ID., The lost Gospel Q, Ulysses Press, Berkeley 1996.

(59) J. P. MeIER, o. c.; E. P. SANDERS, Judaism. Sharper Press 1997. Resalta también el carácter judío y escatológico de la figura de Jesús, E. P. SANDERs, Jesus and Judaism, Fortress Press, Philadelphia 1985; ID., The Historical Figure of Jesus, Penguin, London 1993; M. CASEY, From Jewish Prophet to gentile God: The Origins of Development of New Testament Christoloy, John Knox Press, Wesminster 1991; ID., Is John's Gospel true?, Routledge, London 1996.

(60) Ninguno de estos retratos pone en cuestión la realidad histórica de Jesús ni agotan su identidad, pero no están exentos de una cierta parcialidad y, a veces, no desprovistos de prejuicios ideológicos. Son tantas y tan variadas las imágenes de Jesús como tantos son los investigadores que se interesan en el tema. Por momentos da la impresión de que la actual investigación podría caer en una versión nueva, aunque con rasgos distintos, de las historias de Jesús de la escuela liberal, en donde se presentan imágenes de Jesús a la carta y para todos los gustos. Es muy crítico frente a las imágenes de Jesús que resultan de las investigaciones de la Third Quest y de sus presupuestos y el proceso metodológico utilizado, el libro de BEN WITHERINGTON III, The Jesus Quest. The Third Search for the Jew of Nazareth. Intervarsity Press, Illinois 1995 (edición aumentada, 1997).

(61) Hay que señalar que varios de los más renombrados escrituristas norteamericanos no pertenecen a este grupo -por ejemplo, el ya fallecido R. E. Brown o J. A Fitzmyer- y que las posiciones de los miembros de este colectivo son muy variadas y dispares. 
Estos estudiosos se intercambian permanentemente sus investigaciones y dos veces al año se reúnen algunos de ellos para votar sobre la historicidad de los dichos de Jesús. El procedimiento es este: introducen en un recipiente elementos de varios colores. Se le asigna un color a cada valor histórico que se conceda a un dicho de Jesús: el rojo significa que el dicho atribuido a Jesús es indudablemente suyo ("That's Jesús"); el rosado, que Jesús probablemente dijo algo así ("sure sounds like Jesus”); el gris, que Jesús no dijo exactamente eso, pero que la idea contenida en el dicho sí es suya ("Well, maybe”); el negro, que Jesús no dijo eso y que más bien pertenece a una tradición tardía o diferente ("There's been some mistake"). Las discusiones y conclusiones de las reuniones semestrales se publican en la revista Foundations and Facets Forum, fundada y dirigida por el portavoz del seminario, Robert W. Funk (62).

En 1993 publicaron una obra titulada The Five Gospels (63) en donde se recoge el resultado de sus investigaciones hasta ese momento. En esta obra hacen una traducción, realizada por ellos mismos, de los cuatro evangelios y del evangelio de Tomás. Su conclusión es que solo el 18 por ciento de las palabras que los evangelios ponen en boca de Jesús pudieron haber sido pronunciadas por él. Al evangelio de Juan le conceden muy poco valor histórico y, aunque aceptan la teoría de las dos fuentes, al evangelio de Marcos lo consideran tardío y de poco valor. La importancia decisiva se la conceden a la fuente Q y al evangelio de Tomás. La figura de Jesús que resulta de sus consideraciones es la de un sabio marginal, contracultural al estilo de los filósofos cínicos, que predica un Reino ya presente sin ninguna connotación escatológica o apocalíptica y que critica fuertemente la organización de su entorno, promoviendo una auténtica revolución social.

Dos cuestiones vale la pena resaltar de la metodología del "Jesus Seminar", sobre todo, con relación al valor que se le concede a los escritos considerados apócrifos y al uso de los criterios de autenticidad histórica. Respecto a los escritos apócrifos y su importancia para un mayor conocimiento del Jesús histórico la atención se ha centrado principalmente en el llamado evangelio de Tomás. Los autores han dividido sus opiniones respecto a este evangelio: unos son completamente optimistas y otros escépticos frente a los aportes que este evangelio ofrece para el conocimiento de Jesús. H. Koester, J. M. Robinson, J. D. Crossan y S. J. Patterson, sostienen que este evangelio contiene tradiciones sobre Jesús que son independientes de los evangelios sinópticos, las cuales se remontarían a un período anterior al año 70 d.c. Particularmente, Crossan, considera que el evangelio de Tomás, junto con otros documentos, como el evangelio de Pedro, el evangelio secreto de Marcos y el papiro Egerton 2, constituyen cuatro testigos excepcionales sobre el Jesús histórico, ya que, según él, ellos conservan tradiciones paralelas y/o anteriores a los evangelios sinópticos y por eso los llama los "otros cuatro evangelios", que él

(62) Esta forma de proceder para decidir sobre la historicidad de algún dicho de Jesús es bastante cuestionable, pues la verdad histórica no se puede decidir por votación, sino por la fuerza misma de los argumentos que confluyen a favor de lo que se quiere averiguar.

(63) R. W. FunK-R. W. Hoover (EDS.), The Five Gospels: The Search for the Authentic Words of Jesus, New York 1993; R. W. Funk, Jesus Seminar. The Five Gospels, Harper Collins, San Francisco 1997. 
considera como cuatro evangelios "alternativos, hasta el punto de considerar los evangelios canónicos como representantes del cristianismo oficial, eclesiástico y tradicional, mientras que los cuatro evangelios alternos serían como los cuatro evangelios "canónicos" consagrados por la crítica histórica (64). G. Theissen piensa que la antigüedad de las tradiciones contenidas en Tomás solo se remonta a un período anterior al año 145 d.c. Otros autores como W. Schrage, R. E. Brown y R. M. Grant sitúan a Tomás en el siglo II d.c. y J. P. Meier y el mismo G. Theissen, consideran que el evangelio de Tomás utilizó a Mateo y Lucas, lo que hace de él una fuente totalmente secundaria en la búsqueda del Jesús histórico.

En todo caso la cuestión en torno al evangelio de Tomás y su importancia para el mayor conocimiento del Jesús histórico es una cuestión que todavía sigue abierta. Dentro de ella se tienen que resolver cuestiones como la fecha de composición que hasta el estado actual de la investigación no va más atrás de la destrucción de Jerusalén. También hay que aclarar el proceso de tradición y composición de Tomás y estudiar el significado de los logia que contiene y su relación con Q y con la tradición sinóptica.

Respecto a los criterios de autenticidad histórica, se podría decir que es este uno de los puntos más controvertidos dentro del "Jesus Seminar". La New Quest se caracterizaba por el uso del criterio de discontinuidad o desemejanza, apoyado en el criterio de coherencia y en algún otro criterio secundario. Se pensaba que esos dos criterios podrían conducir a lo que es propio y exclusivo del mensaje y de la vida de Jesús respecto al judaísmo de su época y a la comunidad primitiva. En la Third Quest se revisan los criterios mencionados y se proponen nuevos criterios.

Parece ser que el uso del criterio de discontinuidad en la New Quest se basa en una confusión entre "lo diferente" y "lo característico", de tal manera que se establece lo que es auténtico y se va automáticamente al mensaje de Jesús para identificarlo, sin considerar que algunos elementos esenciales de ese mensaje pueden coincidir con elementos del judaísmo y de la comunidad primitiva. La Third Quest llama la atención sobre los peligros en los que se puede caer por el uso mecánico del criterio de discontinuidad. Por una parte la confusión, al identificar "lo diferente" y "lo característico", puede llevar a que elementos secundarios en el ministerio de Jesús aparezcan como centrales. Por otra parte, si los elementos que vinculan a Jesús con el judaísmo y la comunidad primitiva son descartados se corre el riesgo de construir una imagen arbitraria de Jesús; además, la pretensión de hacer emerger la originalidad de Jesús, con relación al judaísmo y a la comunidad primitiva, utilizando la exclusión, requiere conocer muy bien esas dos realidades. Esto exige que el criterio de discontinuidad se deba aplicar más bien en sentido positivo, es decir, introduciendo elementos de continuidad con el judaísmo o con el cristianismo primi-

(64) Cf. J. D. CRossan, Four Other Gospels, Minneapolis 1985. Este autor llega, incluso, a afirmar que detrás del evangelio de Pedro se encontraría el "evangelio de la cruz", que sería como una fuente común a los relatos de la pasión de los evangelios sinópticos. G. Theissen piensa que el evangelio de Pedro 8, 28-11, 49 sería el relato más antiguo de la resurrección de Jesús, que dataría de la segunda mitad del s. II, pero que se basa en un relato antiguo de la pasión y de la resurrección independiente de los sinópticos (Cf. G. THEISSEN- A. MERZ, El Jesús histórico, Sígueme, Salamanca 1999, 549). 
tivo. A partir de este dato los estudiosos vinculados a la Third Quest han intentando la reformulación del criterio de discontinuidad y se ha hecho ver la necesidad de usar con prudencia y de una manera nueva los criterios que desde la New Quest se habían establecido (65).

\section{El carácter "biográfico" de los evangelios}

En el año 1915, Clyde Weber Votaw (66) había dicho que era posible ubicar los evangelios dentro del ámbito de la literatura biográfica popular grecorromana, de manera semejante a como Platón biografió la vida de Sócrates o la biografía que Filóstrato hizo de su maestro Apolonio de Tiana o a la que Arriano hizo de Epícteto.

Los exponentes de la escuela de las formas se habían opuesto a la interpretación biográfica de los evangelios, pues consideraban que estos no tenían ningún propósito biográfico. Ha sido a partir de la crítica literaria llevada a cabo, sobre todo, por estudiosos ingleses y norteamericanos (Peter Georgi, David Laurence Barr, Judith L. Wentling; Gilbert G. Bilezikian, entre otros) que se ha ido superando la posición de la FG de considerar los evangelios como relatos legendarios y desinteresados por la historia.

En este sentido es de especial importancia el aporte de Graham N. Stanton (67) en 1974 quien, analizando el evangelio de Lucas, asegura que este evangelista presenta una abundante información sobre la vida y el carácter de Jesús de Nazaret. A partir del análisis de las biografías antiguas que él mismo realiza, llama la atención sobre el hecho de que en muchas de ellas faltan algunos elementos que hoy se consideran importantes, como son la cronología y el desarrollo del carácter sicológico del héroe y concluye que los evangelios son escritos de carácter biográfico en el sentido que ellos son verdaderas y propias vidas de Jesús, a la manera de los relatos biográficos antiguos del mundo grecorromano.

En esta misma línea van los estudios del inglés Charles H. Talbert (68) en 1978, de Philip Schuler (69) en 1982, quien hacía notar el carácter biográfico del

(65) Theissen propone reformular el criterio de discontinuidad a partir de lo que él llama criterio de "plausibilidad histórica" (Plausibilitätskriterium), que se podría formular así: puede ser considerado histórico todo lo que contribuya a explicar el influjo o impacto de Jesús sobre el cristianismo primitivo y que, al mismo tiempo, solo puede haber surgido en un contexto judío. Este criterio tiene en cuenta, de una manera positiva, la relación entre Jesús y la comunidad primitiva -el impacto- y la relación entre Jesús y el judaísmo -el contexto- (Cf. G. THEISSEN, o. c., 139-142). En este mismo sentido se replantea el criterio de coherencia, pues se puede caer en el subjetivismo al tratar de decidir hoy lo que era coherente en el momento histórico de Jesús. El mal uso de este criterio podría llevar a descartar como inauténticos algunos elementos que, vistos desde hoy, no se verían como coherentes con el mensaje de Jesús, o puede suceder también lo contrario: que se consideraran como auténticos, elementos coherentes con el mensaje de Jesús que pudiesen haber sido creados por la comunidad primitiva (Cf. J. MEIER, o. c., 191-192).

(66) C. W. Votaw, The Gospels and Contemporary Biographies, en "American Journal of Theology" 19 (1915) 45-73. Este estudio fue reeditado en 1970 con el título: The Gospels and Contemporary Biographies in the Graeco-Roman World, Fortress Press, Facet Books 1970.

(67) G. N. Stanton, Jesus of Nazareth in New Testament Preaching, University Press, Cambridge 1974.

(68) C. H. TAlberT, What is a Gospel? The Genre of the Canonical Gospels, SPCK, London 1978.

(69) P. SCHUler, A Genre of the Gospels: The Biographical Character of Mathew, Fortress Press, Philadelphia 1982. 
evangelio de Mateo y, sobre todo, la importante obra en esta dirección de Klaus Berger en 1984, que en un estudio titulado: "Géneros literarios helenísticos del Nuevo Testamento" (70) muestra, refutando la teoría bultmanniana, que los evangelios están muy cerca de las biografías de los filósofos antiguos y que Mateo y Lucas tienden a presentar a Jesús como un rey.

Pero es principalmente Richard A. Burridge (71) quien, en 1992, recogiendo y haciéndose expresión nítida de casi un siglo de estudios en esta línea, afirmaba que ya era hora de aplicar decididamente el adjetivo "biográfico" a los evangelios ya que ellos pertenecen al género Bíoi. Él mismo se pone en la tarea de comparar los evangelios con 10 biografías antiguas del mundo judío y grecorromano y presenta importantes argumentos para afirmar categóricamente que los evangelios bien pueden considerarse dentro del género literario Bíoi (vidas). Según él son cuatro las principales características de este género literario:

- Notas introductorias: título, que también puede contener el nombre del género (tragedia, autobiografía, historia, vida); prólogo, que permite una cierta identificación del género (parecido al inicio de las cartas de Pablo).

- $\quad$ Sujeto: héroes, filósofos, maestros, emperadores.

- Características externas: manera de representar el sujeto, estructura, tamaño de la obra (si las narraciones históricas son más bien largas; las monografías tienen una extensión mediana), uso de las fuentes escritas y orales; métodos de caracterización del héroe.

- Características internas: escenario, estilo, tono, calidad de la caracterización, intención del autor.

De todas maneras la característica más importante de este género es la atención exclusiva al sujeto protagonista. Esta atención se realiza de diversas maneras: unas veces se cubre toda la vida del héroe; otras se ocupan de un solo período y, otras veces, solo se ocupan de algunas temáticas, o enseñanzas o virtudes del protagonista.

En todo caso es posible detectar en los evangelios, según Burridge, algunos elementos comunes con el género bíoi presente en las biografías que él analiza, a saber: el uso de las genealogías; la atención centrada en el protagonista, que en el caso de los evangelios es Jesús; la caracterización del personaje de una manera indirecta a partir de sus hechos y enseñanzas sin interesarse por una presentación física o sicológica del mismo.

Se concluye, entonces, que el género biográfico bien se puede aplicar a los evangelios en correspondencia con la concepción literaria del tiempo. Así, los evangelios no son solo historia de la experiencia cristiana de las primeras comunidades, sino que ellos tienen un verdadero interés en la historia de Jesús y, al estilo de la época, ellos se ocupan en sus relatos de narrarla.

(70) K. BERGER, Hellenistische Gattungen in NT, en "Aufstieg und niedergang der Römischen Welt", II, 25, 2 (1984) 1031-1432.

(71) R. A. Burridge, What are the Gospels? A Comparison with Graeco-Roman Biography, Cambridge, University Press 1992. 
Antes de terminar este apartado dedicado a la Third Quest es importante señalar aquellos elementos que uno de sus propios seguidores presenta como ya adquiridos en esta "tercera búsqueda" de Jesús y que deben ser incorporados a cualquier producción cristológica que se haga hoy en día (72):

- Si las dos primeras investigaciones sobre Jesús se desarrollaron en Alemania en el ámbito del protestantismo liberal, ahora la investigación se realiza en Estados Unidos, Canadá, Bretaña y también Alemania y por personas que se mueven dentro del campo protestante, católico, judío y aun agnóstico, lo que ha ocasionado que la búsqueda alcance hoy una dimensión ecuménicainterconfesional e internacional.

- A pesar de la disparidad de posiciones se ha precisado la cuestión en torno a la confiabilidad de las fuentes acerca de Jesús. Se considera hoy una ganancia el hecho de que, por una parte, se haga una evaluación más seria y un uso más crítico y cuidadoso de las fuentes neotestamentarias, y por otra, se ha valorado en su justa medida y prestado una mejor atención al testimonio extrabíblico de Flavio Josefo sobre Jesús (73).

- Muchos de los retratos de Jesús derivados de la primera y segunda búsqueda están viciados por la deformación que se hace del judaísmo del primer siglo, fruto de la comprensión alemana-evangélica que se hace de la teología de Pablo. El Jesús de Bultmann o de Bornkamm o de Jeremías termina despreciando radicalmente el judaísmo y la visión que este tenía de Dios. La visión de Jesús se consideraba como nueva y original y, como tal, se oponía al modo de ver del judaísmo. Hoy es una ganancia de la Third Quest el tomar en serio, en toda su complejidad y riqueza, el judaísmo palestinense del siglo I y la pertenencia y ubicación de Jesús en él.

- Los nuevos conocimientos que ha aportado la arqueología, la filología y la sociología son realmente grandes y valiosos puesto que permiten colocar mejor a Jesús en su tiempo.

- La aclaración de los criterios de autenticidad permite hacer mejor el enlace entre Jesús, el judaísmo y la comunidad primitiva. Es innegable el progreso que va desde el planteamiento de los criterios que hacía la New Quest al manejo que hoy se hace de ellos, corrigiendo sus limitaciones y restricciones y aun proponiendo nuevos criterios, lo que ha procurado una mayor seguridad en torno al material considerado histórico.

- La New Quest trataba con desdén y manejaba de pasada el material sobre los milagros contenido en la tradición evangélica. Prueba de ello es que la mayoría de los autores que trataban la cuestión (R. Bultmann, M. Dibelius, G. Bornkamm, H. Conzelmann) dedicaban unas pocas hojas al análisis de este

(72) Se trata de la presentación que hizo J. P. MEIER, The Present State of the 'Third Quest for the Historical Jesus: Loss and Gain, en Biblica 80 (1999) 459-487.

(73) Hay que anotar que Meier tiene poco aprecio por la originalidad del testimonio y los aportes que ofrecen las documentos apócrifos sobre Jesús, testimonios estos a los que muchos de los eruditos de la Third Quest conceden bastante valor (cf. la obra citada de Meier, tomo I. Págs 131-182). 
material. Hoy en día se valora positivamente -aunque se tenga una interpretación diversa del sentido que se deba conceder a las acciones milagrosas de Jesús (74)-, la presencia masiva de la tradición de los milagros en las fuentes. Se dice que son precisamente sus acciones milagrosas, de las cuales dan abundante testimonio los evangelios, lo que explica la inmensa popularidad de Jesús entre las muchedumbres de Palestina.

- $\quad$ La Third Quest se ha tomado en serio el judaísmo de Jesús, pues la fuentes que hoy se poseen permiten argumentar con fuerza la influencia religiosa y cultural del judaísmo nativo de Palestina en la vida y el mensaje de Jesús. Es tan cierto y completo el judaísmo de Jesús que si se dice que Jesús es verdaderamente hombre y verdaderamente Dios, hay que afirmar que la humanidad de Jesús no es algo meramente genérico, pues es verdaderamente hombre porque es precisa y verdaderamente judío. Es este un dato que debe incorporarse a hoy cualquier reflexión cristológica.

\section{CONSIDERACIÓN FINAL}

Después de recorrer el camino de la evolución de la crítica respecto al llamado Jesús histórico y, sobre todo, al tratar de leer la ingente producción que en los últimos años se viene publicando, pareciera, por una parte, que es imposible seguir el ritmo de las investigaciones, que se producen casi a diario y, por otra, que son tantas las divergencias en la comprensión de cuestiones importantes y decisivas que se tiene la sensación de que es imposible hoy asegurar algo cierto respecto a Jesús.

Aunque esta pudiera ser la sensación, es innegable que la investigación histórica respecto a Jesús ha alcanzado puertos de llegada ciertos, que por lo demás se presentan como puntos de referencia para continuar la investigación, la cual, como se decía al comienzo, es irrenunciable y exigencia de la fe misma y de la teología.

Nos limitamos a mencionar solo dos de los datos ya adquiridos, que por sí mismos acreditan la importancia de la investigación hecha hasta hoy y que se constituyen en faros iluminadores para la fe y la reflexión cristológica futura:

- $\quad$ El reconocimiento de que la fe no nace de ella misma. El fundamento de las afirmaciones pascuales de los discípulos hacen referencia a un acontecimiento histórico: Jesús de Nazaret. Pese a que los evangelios son eminentemente testimonios de fe, no dejan nunca de referirse al acontecimiento original y originante de ella: Jesús de Nazaret.

- $\quad$ El material evangélico que la crítica reconoce hoy como auténtico es abundante. Dicho material, por su cantidad y calidad, permite alcanzar los rasgos centrales de la vida humana de Jesús y de su proyecto de vida. Sin que se pretenda

(74) Algunos piensan a Jesús como un mago (Cf. Morton S., Jesus the Magician, San Francisco 1978; E. P. SANDERS, Jesus and Judaism, Fortress Press, Philadelphia, 1985, 157-173) o como los magos helenistas de aquel momento (cf. J. D. CROSSAn, Historical Jesus as Risen Lord, Trinity Press, Valley Forge 1999, 303-353). 
constituir la investigación histórica en norma y criterio de la fe, el encuentro con este dato permite verificar cómo el contenido de la fe de la primitiva comunidad fue llenado por el Jesús terreno, lo que evita la sospecha de que la proclamación sobre Cristo, bien sea el anuncio primitivo o el actual, sean un simple mito o una mera proyección de la fe sin asiento alguno en un hecho histórico.

Sin embargo, queda una cuestión pendiente que es fundamental seguir aclarando y precisando en esta problemática debido a las profundas implicaciones teológicas que ella conlleva. Se trata de la manera como se relacionan fe e historia. Es esta la cuestión que siempre ha animado, motivado y jalonado la búsqueda del llamado Jesús histórico y que, como se decía, toca lo más hondo de la fe misma.

En la llamada Old Quest la historia y la fe se opusieron desde el planteamiento hecho por Reimarus y su discípulo Lessing. Según aquel, uno era el proyecto de Jesús y otro el de sus discípulos. La historia de Jesús no importa y es la fe de los discípulos la que se constituye en sí misma en la base del edificio cristiano. Todo lo que se dice de Jesús en los evangelios no es sino la proyección del mito creado por los discípulos. Aquellos no contienen historia, sino que son obras para la fe. Como reacción opuesta a esta posición la escuela liberal se lanza a la tarea de recuperar, mediante una "sólida investigación", la historia de Jesús. Fue este el primer intento de alcanzar la historia y rescatar la humanidad de Jesús, recuperando su "biografía", mediante una artificiosa pretensión de armonizar los datos de los evangelios y comprenderlos racionalmente limpiándolos de los retoques del kerigma.

M. Kähler, Strauss y, sobre todo, Bultmann radicalizan la oposición, protestando contra los intentos liberales de encontrar a Jesús y hacer la reconstrucción histórica de su personalidad y su vida. Este, les parece, es un proyecto inalcanzable, además inútil e innecesario. Ni a los evangelios les interesa ni a nosotros tampoco debe interesarnos la historia de Jesús. Esta no tiene ningún significado para la fe. Los evangelios son obras dirigidas fundamentalmente a la fe. De esta manera, a partir de Bultmann, entre la historia y la fe no hay ninguna relación sino un foso profundo que las separa.

Es la New Quest la que se propone aproximar el Jesús histórico y el Cristo proclamado en el kerigma pascual. La historia es necesaria para la fe y hay que recuperar esa historia. Los criterios de autenticidad histórica, sobre todo el criterio de discontinuidad, se convierten en el instrumental metodológico que permite acceder a esa historia, pero a su vez, es ese mismo criterio el que mantiene la tensión entre Jesús y la comunidad postpascual y entre Jesús y el judaísmo. De esta manera la vieja fosa entre historia y fe, abierta desde Reimarus y Lessing, se mantiene.

La Third Quest también es deudora de esta problemática. Es un hecho logrado la confianza que los investigadores tienen en la posibilidad del acceso a la historia y al mensaje de Jesús, de tal manera que ya se cuenta con un buen número de certezas acerca del Jesús histórico. Sin embargo, aunque es cierto que la problemática en torno a la relación entre historia y fe presenta hoy connotaciones nuevas y diversificadas, la cuestión última sobre los vínculos que existen entre estas dos realidades no alcanza todavía a tener una solución presentable.

J. D. Crossan no tiene problemas en identificar la fe cristiana con el acto de fe en el Jesús histórico, en quien él ve la manifestación directa de Dios. El Jesús histórico reconstruido por los exégetas es el objeto propio de la fe, y en la medida en que ese 
Jesús del pasado se le interprete con relación al presente se hace más significativo para el hoy. De esta manera para Crossan la regla de la fe no es el Evangelio, sino la reconstrucción crítica que los investigadores hacen de él. La fe cristiana es múltiple porque múltiples son las figuras de Jesús que resultan de la reconstrucción crítica que hacen los exégetas y que actualizan para cada época. En definitiva con la posición de Crossan se vuelve a los intentos del racionalismo liberal de depurar a Jesús de los retoques del kerigma neotestamentario o del dogma eclesial. De nuevo aparece, en versión actual, la vieja oposición entre la historia acontecida y la fe.

J. P. Meier tiene una posición muy diversa a la de Crossan. Para Meier el Jesús histórico es una reconstrucción fruto de la investigación crítica moderna y como tal no puede ser objeto de la fe. Para él, el objeto de la fe es solo Jesucristo muerto, resucitado, sentado junto al Padre y presente en su Iglesia. La condición del exégeta y la del creyente debe distinguirse y separarse: una cosa es lo que se sabe de Jesús como historiador y otra la que se confiesa como creyente (75). Para Meier todos los esfuerzos de reconstrucción histórica sobre Jesús no sirven de mucho a la hora de confesar la fe. Una y otra son dos cosas diversas y están separadas: la fe es, ante todo, adhesión a una persona y solo secundariamente es adhesión a lo que ella dice o a lo que se dice de ella. Otra vez con Meier aparece la vieja oposición, en una versión nueva, entre historia y kerigma. Con Meier no se está lejos de la posición de Bultmann respecto a esta cuestión, aunque con características y matices diversos.

Resulta significativo que tanto Crossan como Meier presenten sendas figuras del Jesús histórico sin poner en duda los datos que van encontrando, pero la significación que le dan al Jesús encontrado es diversa. Mientras que para Crossan la reconstrucción de Jesús hecha por la crítica histórica es esencial para la confesión de fe, dejando así a la comunidad postpascual sin ninguna significación teológica, para Meier la reconstrucción crítica de Jesús no tiene ninguna significación teológica ya que lo esencial a la fe es la significación que para el kerigma tiene Jesús (76).

Ciertamente que no es fácil resolver esta cuestión, pero quizás dentro de una comprensión más holística de la fe, y prestando una mayor atención al camino recorrido por las comunidades primitivas -el proceso de ida desde el novedoso impacto que el resucitado provoca en la comunidad primitiva hasta el contexto judío en el que Jesús se inscribe, y el proceso de vuelta desde el contexto judío hasta el impacto postpascual-, se podría encontrar ese vínculo entre historia y fe; vínculo que las comunidades primitivas han establecido sin ningún problema y del cual es testimonio el Evangelio cuadriforme que hoy poseemos (77). Este este un reto y una tarea importante que la Third Quest debe realizar a partir de las claridades y certezas ya logradas a través de dos siglos de investigación.

(75) Cf. J. MEIER, o. c., Tomo I, 34.

(76) Una profundización sobre las posiciones de Crossan y Meier se encuentra en ARMAND PUIG I TÀRRECH, La recherche du Jésus historique en Biblica 81 (2000) 179-201.

(77) Este es tal vez el sentido del criterio de "plausibilidad histórica" formulado por G. Theissen que se comentaba más arriba. El adecuado uso de este criterio, junto a la utilización de los otros criterios ya reformulados, puede favorecer el hallazgo, cada vez más preciso y mejor, del punto de encuentro entre la fe postpascual y la historia de Jesús de Nazaret que sirvió de base a la "historia" de la cual quieren ser testimonio los evangelios. 


\section{RESUMEN}

El artículo, después de hacer un recorrido por la antigua y nueva investigación sobre el Jesús histórico, fija la atención en lo que se ha denominado como la Third Quest. El propósito es presentar el estado actual de la investigación, describiendo los presupuestos, logros y cuestiones discutidas en torno a la búsqueda que hoy se hace del Jesús histórico.

Palabras clave: Jesús Histórico, Cristología, Teología.

\section{ABSTRACT}

This issue, after having gone through old and new research on the historical Jesus, pays special attention to what has been named as the "Third Quest." The idea is to present the actual state of research by describing the hypotheses, achievements and topics discussed around the current search for the historical Jesus.

Key words: Historical Jesus, Christology, Theology. 